Homepage: http://www.ojs.ufpi.br/index.php/jibi

\author{
Gilneia da Rosa ${ }^{1}$ \\ Jonathan Soares de Lima ${ }^{1}$ \\ Arianne Peruzo Pires Gonçalves ${ }^{1}$ \\ Paulo Henrique Sposito ${ }^{1}$ \\ Jady Slaviero Tieppo ${ }^{1}$ \\ Adalgiza Pinto Neto ${ }^{1}$ \\ Luiz Sergio Merlini ${ }^{1}$
}

\section{Universidade Paraense}

KE Y W O R D S

Biosafety; Farms; Pigs.

PALA VRAS - C H A VE

Biossegurança; Granjas; Suínos.

AUTOR CORRESPONDENTE:

Jonathan Soares de Lima

<jonathansoaresdelima@gmail.com>

Universidade Paranaense

Pç. Mascarenhas de Moraes, 4282, Zona III CEP: 87502-210

Umuarama - PR - Brasil

Submetido em: 04/08/2017

Aceito em: 21/12/2017

\section{Artigo original}

\section{Assessment of biosecurity levels in pig farms in the Northwestern region in the State of Parana, Brazil}

\author{
Avaliação dos níveis de biossegurança nas explorações de \\ suínos na região noroeste do estado do Paraná, Brasil
}

\begin{abstract}
A B S T R A C T
The objective of this work was to evaluate the biosafety levels in 50 pig farms located in the Northwest region of the State of Paraná. For the biosafety study, points (ranging from 0 to 3 ) were assigned for each criterion evaluated, such as: distance from other swine units, herd density within a $3.5 \mathrm{~km}$ radius, farms supplying swine females to herd replacement, distance from the road to pork transport, isolation of the farm (hedges and fences, control of visits, existence of quarantine areas, food origin, transport of feed). Of the 50 properties studied, the following results were obtained: 50 farms are located more than $3.5 \mathrm{~km}$ from other units producing pigs or roads; some have more than one supplier to replace the animals in the herd. Regarding visitor control, 28 receive occasional visits with a 24 -hour sanitary interval, none have a bathing system with clothing and shoes, and a bathroom with a clean and dirty area, 22 are not visited, and all have baths. boot, with all employees wearing boots. Seven farms offered food manufactured by third parties; all presented fences dividing the internal perimeter; all transported food and / or raw materials with a bulk carrier. Only 13 produced their own female breeding and swine. All of them performed sanitary rupture, pest control and provide chlorinated water, also used composting for dead animals, placenta and abortions. No farm reached the maximum score, since all presented some fault in the biosafety system.
\end{abstract}

\section{RE S U M O}

O objetivo deste trabalho foi avaliar os níveis de biossegurança em 50 granjas de suínos, localizadas na região Noroeste do Estado do Paraná. Para o estudo de biossegurança, foram atribuídos pontos, variando de 0 a 3 , em cada critério avaliado: distância em relação a outras unidades suinícolas, densidade de rebanho em um raio de $3,5 \mathrm{~km}$, granjas que fornecem as fêmeas suínas para a substituição do rebanho, distância da estrada para o transporte dos suínos, isolamento da granja (sebes e cercas, controle de visitas, existência de áreas de quarentena, origem alimentar, transporte de ração). Das 50 propriedades estudadas, obtiveram-se os seguintes resultados: 50 granjas estão situadas a mais de 3,5 km de outras unidades de produção de suínos ou estradas; algumas têm mais de um fornecedor para substituir os animais no rebanho. No que diz respeito ao controle de visitantes, 28 recebem visitas ocasionais, com intervalo sanitário de 24 horas; nenhuma tem sistema de banho com vestuário e troca de calçados e banheiro com área limpa e suja; 22 não recebem visitas e todos eles têm banhos de arranque, com todos os empregados usando botas. Sete granjas ofereceram alimentos fabricados por terceiros; todas apresentaram cercas dividindo o perímetro interno e transportaram alimentos e / ou matérias-primas com um graneleiro. Apenas 13 produziram suas próprias fêmeas suínas e reprodutores. Todos eles realizaram ruptura sanitária, controle de pragas e forneceram água clorada; também usaram compostagem para animais mortos, placenta e abortos. Nenhuma granja atingiu a pontuação máxima, uma vez que todos apresentaram alguma falha no sistema de biossegurança. 


\section{INTRODUCTION}

Biosecurity is a technical term establishing a set of handling practices and safety standards for living beings by protecting them against live organisms responsible for transmitting of acute and/or chronic diseases in a specific population (BORDIN et al., 2005). Therefore, biosecurity concern in pig farming is an eminent need in order to meet international demands, and also ensure both animal and human health (SOBESTIANSKY, 2002).

According to Santos (1999), biosecurity or biosafety is simply the set of programs and measures designed with the fundamental objective of significantly decreasing the unavoidable exposure of animals to infectious agents and natural predators.

Intensive pig farming has been challenged by a growing number of emerging or re-emerging infectious agents, whether bacterial or viral ones. As a consequence, the use of antibiotics and chemotherapeutic drugs has followed these changes. Even if such valuable pharmacological tools are able to correct deviations in the productive route, the existing zoo-technical potential is not fully achieved when there is a disease. In this sense, the productive sector has been increasingly more concerned in ensuring the health of the herds (HECK, 2005).

Amass (2004) suggests that another important step is the identification of the potential sources poising greater risk of introducing the agent to the herd. According to Morés et al., (2015), the main infectious agents that affect swine are: Salmonella choleraesuis, S. Typhimurium, S. Panamá, Senftenberg, S. Derby and S. Mbandaka, Toxoplasma gondii, Escherichia coli enterotoxigenic, Lawsonia intracellulare, Brachyspira pilosicoli, Streptococcus suis, Mycoplasma hyopneumoniae, Actinobacillus pleuropneumoniae, Pasteurella multocida, Haemophilus parasuis, influenza A vírus and circovírus type 2 (PCV2) and Actinobacillus pleuropneumoniae.

The aim of this research was to assess the biosecurity levels of 50 pig farms in the northwestern region in the state of Paraná, Brazil.

\section{MATERIAL AND METHODS}

The study was performed on 50 pig farms, located in the northwestern region in the state of Paraná between March and October 2013.

The sample size was calculated considering a 5\% estimated prevalence and 95\% confidence level, as recommended by Thrusfield (1986).

The farms were randomly selected; 30 farms working with a full cycle: pre-gestational (mating), gestational, maternity, crèche, re-breading and slaughtering; 15 only with slaughtering, and five with production of piglets.

In order to assess the biosecurity of the farms, a questionnaire containing 27 questions on biosecurity was applied in order to score the production unit, with three points for the safest characteristics, and zero for the most unsafe characteristics.

The biosecurity levels of the farms were checked by studying the vulnerability conditions for the entrance of pathogens in the farm.

\section{STATISTICAL ANALYSIS}

The statistical analysis performed was descriptive, represented by the MODA calculation, most frequent variable value. For each variable estimated, the MODA value was calculated according to Vieira (1980).

\section{RESULTS AND DISCUSSION}

From the 50 farms studied herein, presented scores differing from each other. Therefore, 12 farms were classified with grade three; 32 farms received grade two and six received grade zero.

From the surveyed farms, 17 are in less than $3.5 \mathrm{~km}$ from other farms and 11 are near the roads. The location of the farm might influence the occurrence of diseases, mainly the airborne ones. Therefore, it is recommended to assess the distance of the farm in relation to primary and secondary roads. When choosing a location to build high biosecurity farms, the activities developed in neighboring properties must be taken into consideration, as well as the pig density in the area, the size of the nearest pig farms, the temperature and humidity patterns in the region, the direction of predominant winds, the availability of water in appropriate amount and quality, and the amount of waste generated by the pig production system in the farm itself or in the neighborhood (SOBESTIANSKY, 2002).

All farms presented fences delimiting their external perimeter, so as to avoid the entrance of people, wild or domestic animals. A total of 31 farms were positioned at a minimum distance of 05 to 10 meters from the facilities; 19 presented employee houses within their perimeter.

The perimeter fences on the facilities must totally prevent the entrance of humans, wild and domestic animals. In the case of high biosecurity farms, they must protect even the area below the fence for at least $30 \mathrm{~cm}$, thus avoiding the penetration of animals who excavate the earth on the bottom of the fence (SOBESTIANSKY, 2002).

The implementation of physical barriers (trees) is recommended around each nuclei. However, it is very important that such barrier be large enough to truly act as a barrier. That is, just a few lines of trees can hardly be considered an efficient barrier. A suggestion would be to plant a barrier of fast-growing trees (such as pinus or eucalyptus) with approximately 50 meters wide. The lines must not match so as to not allow the direct passage of wind between the trees.

Water is the only positive point in all farms, since all of them use chlorinated water from artisan wells. According to 
Da Rosa, G. et al.

\begin{tabular}{|c|c|c|c|}
\hline Variables analyzed & Criterion & Ratings & Obtained on the farm \\
\hline 1) Distance from other pig units & $\begin{array}{l}\text { Greater than } 3.5 \mathrm{~km} \\
\text { Within } 1 \text { to } 3 \mathrm{~km} \\
\text { From } 500 \mathrm{~m} \text { to } 1 \mathrm{~km} \\
\text { Less than } 500 \mathrm{~m}\end{array}$ & $\begin{array}{l}3 \\
2 \\
1 \\
0\end{array}$ & - \\
\hline $\begin{array}{l}\text { 2) Density of herd within a radius of } \\
3.5 \mathrm{~km}\end{array}$ & $\begin{array}{l}1 \text { herd } \\
2 \text { to } 3 \text { herds } \\
4 \text { or more herds }\end{array}$ & $\begin{array}{l}2 \\
1 \\
0\end{array}$ & $\ldots$ \\
\hline $\begin{array}{l}\text { 3) Farms supplier of swine females } \\
\text { for replenishment of the stock }\end{array}$ & $\begin{array}{l}\text { Own repositioning } \\
1 \text { supplier } \\
2 \text { suppliers } \\
3 \text { or more suppliers }\end{array}$ & $\begin{array}{l}3 \\
2 \\
1 \\
0\end{array}$ & - \\
\hline $\begin{array}{l}\text { 4) Distance from road transporting } \\
\text { pigs }\end{array}$ & $\begin{array}{l}\text { Greater than } 500 \mathrm{~m} \\
300 \text { to } 500 \mathrm{~m} \\
\text { Less than } 300 \mathrm{~m}\end{array}$ & $\begin{array}{l}3 \\
2 \\
0\end{array}$ & - \\
\hline $\begin{array}{l}\text { 5) Quality of farm insulation - } \\
\text { fencing }\end{array}$ & $\begin{array}{l}\text { Fence interspersed with green belt } \\
\text { Only fence or green belt } \\
\text { No fences or green belt }\end{array}$ & $\begin{array}{c}3 \\
2-1 \\
0 \\
\end{array}$ & - \\
\hline 6) Existence of quarantine & $\begin{array}{l}\text { Yes } \\
\text { Introduces pigs without quarantine period }\end{array}$ & $\begin{array}{l}3 \\
0\end{array}$ & - \\
\hline 7) View control on the farm & $\begin{array}{l}\text { 72-hour sanitary vacuum, bathing system with } \\
\text { changing of clothes and shoes } \\
\text { Toilet empty for } 48 \text { hours, bath system with } \\
\text { clothes and shoes change } \\
24 \text { hour sanitary empty, bathing system with } \\
\text { change of clothes and shoes } \\
\text { Absence of empty sanitary, without bathing } \\
\text { system with change of clothes and footwear }\end{array}$ & $\begin{array}{l}3 \\
2 \\
1 \\
0\end{array}$ & - \\
\hline
\end{tabular}

Table 01. Biosafety characteristics analyzed for the classification of properties with scores from 0 to 3 .

Silveira et al. (1998), water can be considered one of the most important factors within an activity, whichever this activity may be. Its origin and qualities both in microbiological and chemical aspects, must be strictly obeyed. Semi-artisan wells or similar must be implemented in the project in order to meet the demands mentioned, as well as the qualitative factor, since the animals must have water not only with good quality, but in enough quantity throughout all seasons of the year.

According to Penz Júnior; Viola (1995), the water contamination risk is high, mainly superficial waters, which can be contaminated either directly (by contact with the animals) or indirectly (by the water flow originated from locations where the animals are maintained). The presence of fecal coliform in the water can be used as an indication of contamination by fecal matter, and the concentration of this indicator provides information on the contamination extension.

All farms had a cleaning and disinfection program for the facilities, which is one of the main aspects in the set of handling practices present in farms with efficient and profitable pig farming. In confined conditions, the frequency and severity of diseases are directly related to the level of environmental contamination and this, in turn, is related to the facility's handling system and the cleaning and disinfection program (SOBESTIANSKY et al., 1998).

According to Bordin e outros, (2005), the break period, which is the period between the exchange of batches, must be used in order to reduce the amount of microorganisms. This period can range from seven to ten days; a shorter break than this might increase the possibilities of problems in the health of the following batch to be stored.

According to Sobestiansky e outros, (1998), the sanitary break is a complementary activity to disinfection, allowing the destruction of microorganisms not affected by it, but which have become more sensitive to the action of natural physical pressures. Moreover, the sanitary break allows the facilities to dry. Its efficiency is only possible if the area remains closed, not allowing the passage of animals or people. Only three farms stated that they did not have a seven-day sanitary break.

Among the farms studied, 25 allowed visits; in 38 the employees live outside the property. This jeopardizes the biosecurity of the farms, since the flow of people entering the production units is usually very high, and the organization of this activity constitutes an important biosecurity component. Despite the potential risk human beings represent to the transmission of pathogenic agents, there is little real evidence that this risk can be really translated into the transmission of diseases (AMASS et al., 2000).

Regarding the entrance of vehicles to the farm, $100 \%$ allowed the entrance for loading the animals and entrance of feed and/or raw material for manufacturing feed. According to Poumian (1995), all and any vehicle used for the transportation of animals, equipment and products from 
animal origin, feed and waste must be considered high risk factors for the dissemination of diseases.

From the farms studied, 13 produce their own female swine and reproducers, and 32 acquire them from a single supplier, while five of them acquire them from more than one supplier. The choosing and acquisition of new animals is a very important factor in preventing diseases. The acquired animal can be a carrier for several diseases, without necessarily presenting any signs of being ill. The acquisition of animals from certified farms is recommended (ANDREOTTI; GUIMARÃES, 2003).

Regarding quarantine, $80 \%$ do not use it since they do not acquire animals from other farms; $20 \%$ acquire piglets from other producers, but do not quarantine them. According to Gomes (2007), quarantine is the isolation and concomitant observation of animals in a separate (isolated) facility, before introducing them into the destination herd. The aim is to protect the purchased herd against the introduction of new infectious agents that may cause economically significant diseases.

Feed may also be a source of transmission of diseases; therefore, it is important to check their origin, purity and nutritional value. Ready-made feed must not be stored for a period greater than four weeks, according to Ferreira (1993). Seven farms offered food manufactured by third parties.

Regarding the destination of dead animal carcasses, $100 \%$ of the farms use composting. The carcasses of dead animals are a source for the entrance of diseases in the farm. The exposure of these carcasses favors the incidence of vectors and provides an increase in the infections in the facilities (BORDIN et al., 2005).

From the 50 farms studied, 23 had control for flies and mosquitoes, which can act as vectors for virus, bacteria and fungi. In its routine on the farm, the fly alternates its presence preferably among dunghills, waste gutters and feed gutters, especially the most palatable ones. Virus such as vesicular stomatitis is transmitted to pigs from naturally infected mosquitoes.

All farms stated they perform constant control of domestic rodents (rats and mice), which is important to keep a good biosecurity level, since these animals represent important problems to pig farming, since they cause losses that include damages to the structure of the facilities and the water supply system, feed consumption, generation of feed palatability issues (due to contamination with urine or feces) and microbial contamination of pigs and the environment (SESTI, 2005).

According to Neto (1998), rodents are responsible for transmitting at least 32 diseases to humans and animals. Water disinfection systems using chemical products (i.e. chlorine), ultraviolet rays, or the addition of organic acids must be implemented in order to prevent the introduction of several pathogens through drinking water (Pasteurella, Salmonella).
The entrance of wild birds and animals searching for food was confirmed in seven pig farms, since none of them presented protection against birds. According to Neto (1998), pathogens present in the feet of birds and feces may contaminate feed and soil.

\section{CONCLUSÃO}

None of the farms studied presented $100 \%$ security, which might jeopardize the safety of the herds. The farms with less technology in the breeding, and facilities that are not properly adapted to biosecurity are more vulnerable to the entrance of pathogens. Therefore, it is necessary to increase the epidemiological vigilance in these farms, with the main objective of protecting the health of the pig reproducing herds.

\section{REFERÊNCIAS}

ANDREOTTI, M. O.; GUIMARÃES, E. B. Biosseguridade na produção de suínos. In: SIMPÓSIO SOBRE NUTRIÇÃO DE AVES E SUÍNOS, 1, 2003, Cascavel. Anais... Cascavel: [s. n], 2003. 12 p.

AMASS, S. F. et al. Investigation of people as mechanical vectors for porcine reproductive and respiratory syndrome virus. Swine Health Production. v. 8, n. 4, p. 161-166, 2000.

AMASS, S. F. Diagnosing disinfectant efficacy. Journal Swine Health and Production. v. 12, n. 2, p. 82-83, 2004.

BORDIN, R. A. et al. Biosseguridade aplicada nas granjas de aves e suínos. Revista de Ciências Veterinárias. v. 3, p. 1-4, 2005. FERREIRA, M. G. Produção de aves: corte e postura. Guaíba: Agropecuária, 1993. 117 p.

GOMES, U. Programa de Biosseguridade: atualização, implementação e resultados práticos. In: SIMPÓSIO INTERNACIONAL DE PRODUÇÃO SUÍNA, 3, 2007, Águas de Lindóia. Anais... Águas de Lindóia: [s. n], 2007. p. 5-8.

HECK, A. Biosseguridade na suinocultura: aspectos práticos. In: SEMINÁRIO INTERNACIONAL DE AVES E SUÍNOS, 5, 2005, Florianópolis. Anais... Florianópolis: [s. n], 2005. p. 1-14.

MADEC, F. Biossecurity on pig units: a major issue for Herd Health Maintenance. In: CONGRESSO BRASILEIRO DE VETERINÁRIOS ESPECIALISTAS EM SUÍNOS, 10, 2001, Porto Alegre. Anais... Porto Alegre, 2001. p. 03-08.

MORÉS, M. A. Z. et al. Aspectos patológicos e microbiológicos das doenças respiratórias em suínos de terminação no Brasil. Pesquisa Veterinária Brasileira, v. 35, p. 725-733, 2015.

NETO, C. C. Controle de roedores. In: SOBESTIANSKY, J. WENTZ I.; SILVEIRA, P. R. S.; SESTI, L. A. C. Suinocultura intensiva: produção, manejo e saúde do rebanho. 2. ed. Brasília: Embrapa, 1998. p. 383-388

PENZ, J. R. A. M.; VIOLA, E. S. Potabilidade e exigências de água nas diferentes faixas etárias. In: CONGRESSO BRASILEIRO DE VETERINÁRIOS ESPECIALISTAS EM SUÍNOS, 7, 1995, Blumenau. Anais... Concórdia:[s.n], 1995. p. 57-67. 
POUMIAN, A. M. Desinfección de loscamiones y tractomiones. Review of the Office International des Epizooties. v. 14, p. 165$171,1995$.

SANTOS, C. H. C. Biossegurança. In: ENCONTRO INTERNACIONAL DE CIÊNCIAS AVIÁRIAS DE UBERLÂNDIA, 3, 1999. Anais... Uberlândia [s.n], 1999. p. 63 76.

SESTI, L. A. C. Biosseguridade em granjas de produtores avícolas. In: MACARI, M.; Mendes, A. A. Manejo de matrizes de corte. 2005. p. 243-322.

SILVEIRA, P. R. S. et al. Manejo da fêmea reprodutora. In: SOBESTIANSKY, J.; WENTZ, I.; SILVEIRA, P. R. S.; SESTI, L. A. C. Suinocultura intensiva, produção, manejo e saúde do rebanho. Concórdia: EMBRAPA - CNPSA, 1998. cap. 8, p. 163196.

SOBESTIANSKY, J. Sistema Intensivo de Produção de suínos: programa de biossegurança. Art 3. Goiânia, 2002, p. 108.

THRUSFIELD, M. Veterinary epidemiology. Oxford: Blackwel Science, 1986. 288 p.

VIEIRA, S. Introdução à bioestatística. Rio de Janeiro: Campos, 1980. $360 \mathrm{p}$. 